\title{
ANALISIS RASIO KEUANGAN UNTUK MENGUKUR KINERJA KEUANGAN PERUSAHAAN PADA PT GUNUNG SALAK SUKABUMI DI SUKABUMI
}

\author{
Dedi Kustiawan \\ Deddy.koestiaone@gmail.co \\ Komputerisasi Akuntansi, AMIK Citra Buana Indonesia
}

\begin{abstract}
In the development of today's increasingly advanced world, competition between one company and the other is getting tougher. Therefore, company management is required to carry out its activities more effectively and efficiently. In order to survive or even be able to develop in the competition, companies must understand the company's condition and performance. To find out the company's performance, an appropriate analysis is needed. And the media that can be used to assess company performance is financial statements. Based on the results of this study stated that the performance of the company PT GUNUNG SALAK SUKABUMI. in 2013 until 2015 when viewed from the Liquidity ratio from 2013 to 2015 the company was said to be liquid because the company was able to cover its current debt and was able to increase its liquidity. Judging from the company's Solvency ratio is not stable, because in 2013 to 2014 there was a decrease then from 2014 to 2015 increased. So that in 2014 the company's capital can cover its debts. While seen from the Profitability ratio that from year to year is not stable, this is due to an increase in profit that is not balanced with an increase in sales causing the ratio of gross profit margin and net profit margin to be unstable. If this is left then the inventory will eventually run out so that investors or owners of capital do not want to invest more capital into the company. While seen from the ratio of the company's activity from year to year has increased this is due to sales at this company is greater than assets, the greater this ratio will be better, so the company has increased.
\end{abstract}

Keywords: liquidity, profitability, ratio

\begin{abstract}
ABSTRAK
Dalam perkembangan dunia saat ini yang semakin maju, persaingan antara perusahaan yang satu dengan yang lainnya semakin ketat. Oleh karena itu, manajemen perusahaan dituntut untuk melaksanakan aktivitasnya secara lebih efektif dan efisien. Agar dapat bertahan atau bahkan mampu berkembang dalam persaingan tersebut, perusahaan harus memahami kondisi dan kinerja perusahaan. Untuk mengetahui kinerja perusahaan, maka diperlukan suatu analisis yang tepat. Dan media yang dapat dipakai untuk menilai kinerja perusahaan adalah laporan keuangan. Berdasarkan hasil penelitian ini menyatakan bahwa kinerja perusahaan PT GUNUNG SALAK SUKABUMI. pada tahun 2013 sampai dengan 2015 bila dilihat dari rasio Likuiditas dari tahun 2013 sampai dengan 2015 perusahaan dikatakan likuid karena perusahaan mampu menutupi utang lancarnya dan mampu meningkatkan likuiditasnya. Dilihat dari rasio Solvabilitas perusahaan tidak stabil, karena pada tahun 2013 sampai 2014 terjadi penurunan kemudian dari tahun 2014 ke 2015 meningkat. Sehingga pada tahun 2014 modal perusahaan dapat menutupi utangnya. Sedangkan dilihat dari rasio Rentabilitas bahwa dari tahun ke tahun tidak stabil, hal ini disebabkan kenaikan laba yang tidak seimbang dengan kenaikan penjualan menyebabkan rasio gross profit margin dan net profit margin tidak stabil. Apabila hal ini dibiarkan maka persediaan lama kelamaan akan habis sehingga para investor atau pemilik modal tidak mau menanamkan modalnya lagi kepada perusahaan. Sedangkan dilihat dari rasio Aktivitas perusahaan dari tahun ke tahun mengalami kenaikan hal ini disebabkan karena penjualan pada perusahaan ini lebih besar dari pada aktiva, semakin besar rasio ini akan semakin baik, sehingga perusahaan mengalami kenaikan.
\end{abstract}

Kata kunci: likuiditas, profitabilitas, rasio

\section{PENDAHULUAN}

Latar Belakang Masalah

Bidang keuangan merupakan bidang yang sangat penting dalam suatu perusahaan. Baik perusahaan besar ataupun perusahaan kecil, mempunyai perhatian besar dalam bidang keuangan, terutama dalam perkembangan dunia saat ini yang semakin maju, persaingan antara perusahaan yang satu dengan yang lain semakin ketat, khususnya antara perusahaan sejenis. Terlebih lagi dengan adanya perekonomian bebas yang pemerintah jalankan saat ini, 
banyak perusahaan yang tiba-tiba mengalami kebangkrutan. Oleh karena itu, agar perusahaan dapat bertahan atau bahkan bisa tumbuh dan berkembang perusahaan harus bisa mencermati kondisi dan kinerja perusahaan.

Media yang dapat dipakai untuk menilai kinerja perusahaan adalah laporan keuangan. Laporan keuangan merupakan hasil akhir proses akuntansi pada suatu periode tertentu yang merupakan hasil pengumpulan data keuangan yang disajikan dalam bentuk laporan keuangan ataupun ikhtisar lainnya yang dapat digunakan sebagai alat bantu bagi para pemakai di dalam menilai kinerja keuangan perusahaan sehingga dapat mengambil keputusan dengan tepat.

Secara umum ada tiga bentuk laporan keuangan pokok yang dihasilkan oleh suatu perusahaan yaitu : neraca, laporan laba-rugi dan laporan arus kas. Laporan yang disusun oleh setiap perusahaan di Indonesia harus mengacu pada Standar Akuntansi Keuangan (SAK), yang disusun oleh Ikatan Akuntansi Indonesia (IAI), disamping itu juga harus memenuhi pula aturan perpajakan dan aturan lainnya sesuai dengan prinsip akuntansi yang berlaku umum agar dapat memenuhi kebutuhan pemakainya.

Untuk menilai kinerja perusahaan diperlukan beberapa tolak ukur. Tolak ukur yang sering digunakan adalah rasio atau indeks, yang menghubungkan data yang satu dengan data yang lainnya. Untuk itu diperlukan suatu analisis yang tepat.

Analisis terhadap laporan keuangan suatu perusahaan pada dasarnya karena ingin mengetahui tingkat profitabilitas (keuntungan) dan tingkat resiko atau tingkat kesehatan suatu perusahaan. Analisis keuangan yang mencakup analisis rasio keuangan, akan sangat membantu dalam menilai prestasi manajemen masa lalu dan prospeknya dimasa yang akan datang.

Jenis analisis bervariasi sesuai dengan pihakpihak yang melakukan analisis. Pihak-pihak yang berkepentingan terhadap analisis rasio laporan keuangan terdiri dari pihak intern yaitu dari pihak manajemen, sedangkan dari pihak ekstern terdiri dari para kreditur, pemegang saham (investor) instansi pemerintah dan karyawan.

Analisis laporan keuangan akan lebih tajam apabila angka-angka keuangn dibandingkan dengan standar tertentu. Standar tersebut dapat berupa standar internal yang diterapkan oleh manajemen, perbandingan historis atau membandingkan angkaangka keuangan dengan masa sebelumnya, membandingkan dengan perusahaan atau industri sejenis.

Penilaian tentang kinerja individu karyawan semakin penting ketika perusahaan akan melakukan reposisi karyawan. Artinya bagaimana perusahaan harus mengetahui faktor - faktor apa saja yang mempengaruhi kinerja. Hasil analisis akan bermanfaat untuk membuat program pengembangan SDM secara optimum. Pada gilirannya kinerja individu akan mencerminkan derajat kompetisi suatu perusahaan.

Dalam buku"performance appraisal" karangan Veithzal Rivai dan Ahmad Fawzi MB, 2007, Rajagrafindo persada.

Kinerja adalah hasil atau tingkat keberhasilan seseorang secara keseluruhan selama periode tertentu didalam melaksanakan tugas dibandingkan dengan berbagai kemungkinan, seperti standar hasil kerja, target atau sasaran atau kriteria yang telah ditentukan terlebih dahulu dan telah disepakati bersama. Jika dilihat dari asal katanya, kata kinerja adalah terjemahan dari kata performance, yang menurut the scribner bantam english distionary, terbitan amerika serikat dan kanada (1979), berasal dari kata "to perform" dengan beberapa "entries" yaitu: (1) melakukan, menjalankan, melaksanakan, ( to do carry out, excute ); (2) memenuhi atau melaksanakan kewajiban suatu niat atau nazar (to discharge of fulfill; as vow); (3) melaksanakan atau menyempurnakan tanggung jawab (to excute or complete an understaking); dan (4) melakukan sesuatu yang diharapkan oleh seseorang atau mesin (to do what is expected of a person machine).

Sehubungan dengan itu, kinerja adalah kesediaan seseorang atau kelompok orang untuk melakukan sesuatu kegiatan dan menyempurnakannya sesuai dengan tanggung jawabnya dengan hasil seperti yang diharapkan. Jika dikaitkan dengan performance sebagai kata benda (noun) dimana salah satu entriny adalah hasil dari suatu pekerjaan (thing done) pengertian performance atau kinerja adalah hasil kerja yang dapat dicapai oleh seseorang atau kelompok orang dalam suatu perusahaan sesuai dengan wewenang dan tanggung jawab masing- masing dalam upaya pencapaian tujuan perusahaan secara legal tidak melanggar hukum dan tidak bertentangan dengan moral atau etika.

Berdasarkan uraian diatas maka penulis tertarik untuk melakukan penelitian dengan judul "ANALISIS RASIO KEUANGAN UNTUK MENGUKUR KINERJA KEUANGAN PERUSAHAAN PADA PT GUNUNG SALAK SUKABUMI DI SUKABUMI".

\section{Permasalahan}

Berdasarkan permasalahanpermasalahan yang akan dianalisis dalam artikel ini penulis mengidentifikasi masalah sebagai berikut : 
1. Kondisi laporan keuangan perusahaan pada PT GUNUNG SALAK SUKABUMI di Sukabumi, belum sesuai dengan harapan perusahaan.

2. Pengukuran kinerja keuangan perusahaan pada PT GUNUNG SALAK SUKABUMI di Sukabumi, belum sesuai dengan standar industri atau standar yang berlaku umum.

\section{Perumusan Masalah}

Laporan keuangan ditunjukan untuk memahami posisi keuangan suatu perusahaan dan menilai kondisi keuangan dimasa lalu. Laporan keuangan memiliki kemampuan untuk menyajikan secara gamblang kondisi keuangan suatu perusahaan, guna memberikan keputusan dimasa akan datang yang informatif.

Berdasarkan hal tersebut maka penulis merumuskan masalah sebagai berikut :

1. Bagaimana kondisi laporan keuangan perusahaan pada PT GUNUNG SALAK SUKABUMI di Sukabumi;

2. Bagaimana kinerja keuangan perusahaan pada PT GUNUNG SALAK SUKABUMI di Sukabumi.

3.

\section{Tujuan}

Untuk mengetahui kinerja perusahaan, maka diperlukan suatu analisis yang tepat. Dan media yang dapat dipakai untuk menilai kinerja perusahaan adalah laporan keuangan.

\section{TINJAUAN PUSTAKA \\ Laporan Keuangan}

Laporan keuangan merupakan alat yang sangat penting untuk memperoleh informasi sehubungan dengan posisi keuangan dan hasil-hasil yang telah dicapai oleh perusahaan yang bersangkutan. Sehingga dapat menggambarkan kondisi keuangan dan hasil usaha suatu perusahaan pada saat tertentu atau jangka waktu tertentu.

Laporan keuangan menurut SAK (2007 : 4) adalah

"laporan keuangan merupakan bagian dari proses pelaporan keuangan yang lengkap, biasanya meliputi neraca, laporan laba-rugi, laporan keuangan (yang dapat disajikan dalam beberapa cara seperti misalnya : laporan arus kas atau laporan arus dana), catatan, dan laporan lain serta memberi penjelasan yang merupakan integral dari laporan keuangan. Disamping itu juga termasuk skedul dan informasi tambahan yang berkaitan dengan laporan tersebut, misalnya informasi keuangan segmen industri dan geografis serta pengungkapan pengaruh perubahan harga".

Laporan keuangan menurut Budi Rahardjo dalam bukunya (2009 : 1), yang berjudul : "laporan keuangan perusahaan" adalah :

"laporan pertanggung jawaban manajer atau pemimpin perusahaan atas pengelolaan perusahaan yang dipercayakan kepadanya, kepada pihak-pihak yang berkepentingan (stake holder) diluar perusahaan; pemilik perusahaan, pemerintahan, kreditor, dan pihak lainnya.

Dari penjelasan diatas dapat ditarik kesimpulan bahwa laporan keuangan merupakan alat untuk menginformasikan kondisi keuangan dalam periode tertentu, yang tediri dari neraca, laporan laba-rugi dan laporan perubahan modal, laporan perubahan posisi keuangan serta catatan atas laporan keuangan.

\section{Tujuan Laporan Keuangan}

Menurut Standar Akuntansi Keuangan (2010 : 4) tujuan laporan keuangan adalah :

1) Menyediakan informasi yang menyangkut posisi keuangan, kinerja serta perubahan posisi keuangan suatu perusahaan yang bermanfaat bagi sejumlah pemakai dalam mengambil keputusan ekonomi.

2) Laporan keuangan disusun untuk memenuhi kebutuhan bersama oleh sebagian besar pemakainya, yang secara umum menggambarkan pengaruh keuangan dari kejadian masa lalu.

3) Laporan keuangan juga menunjukan apa yang telah dilakukan oleh manajemen atau pertanggung jawaban manajemen atas sumber daya yang dipercayakan kepadanya.

Informasi mengenai posisi keuangan, sangat diperlukan untuk dapat melakukan evaluasi atas kemampuan perusahaan dalam menghasilkan kas, dan waktu serta dari kepastian tersebut. Posisi keuangan perusahaan dipengaruhi oleh sumber daya yang dikendalikan, struktur keuangan, likuiditas, dan solvabilitas serta kemampuan beradaptasi dengan perubahan lingkungan.

Informasi kinerja perusahaan, terutama profitabilitas diperlukan untuk menilai perubahan potensial sumber daya ekonomi yang mungkin dikendalikan dimasa depan, sehingga dapat memprediksi kapasitas perusahaan dalam mengahasilkan kas (dan 
setara kas) serta untuk merumuskan efektifitas perusahaan dalam memanfaatkan tambahan sumber daya.

Informasi perubahan posisi keuangan perusahaan bermanfaat untuk menilai aktivitas investasi, pendanaan dan operasi perusahaan selama periode pelaporan. Selain berguna untuk menilai kemampuan perusahaan dalam menghasilkan kas, informasi ini juga berguna untuk menilai kebutuhan perusahaan dalam memanfaatkan arus kas tersebut.

Selain untuk tujuan-tujuan tersebut, laporan keuangan juga menunjukan apa yang telah dilakukan oleh manajemen atau menggambarkan pertanggung jawaban manajemen atar sumber daya yang telah dipercayakan kepadanya.

\section{Jenis laporan keuangan}

Laporan keuangan secara umum meliputi, neraca, laporan laba-rugi, laporan ekuitas, laporan arus kas, catatan laporan lain serta materi penjelasan yang merupakan bagian, integral dari laporan keuangan termasuk juga skedul dan informasi tambahan yang berkaitan dengan laporan keuangan. Laporan keuangan terdiri dari :

\section{Neraca}

Neraca adalah laporan keuangan yang memberikan informasi mengenai posisi keuangan perusahaan pada saat tertentu untuk dapat menggambarkan posisi keuangan perusahaan pada saat tertentu, neraca mempunyai tiga unsur laporan keuangan yaitu, aktiva, kewajiban dan ekuitas.

Menurut Dwi Prastowo dan rifka juliaty (2007 :17), masing-masing unsur tersebut dapat disubklasifikasikan sebagai berikut :

a. Aktiva

Aktiva merupakan sumber daya yang dikuasai perusahaan dapat disubklasifikasikan lebih jauh menjadi lima sub-klasifikasi yaitu :

1) Aktiva lancar

Aktiva lancar yaitu aktiva yang manfaat ekonominya diharapkan akan diperoleh dalam waktu satu tahun atau kurang (atau siklus operasi normal), misalnya, kas, surat berharga, persediaan, piutang, dan persekot biaya.

2) Aktiva tetap

Aktiva tetap yaitu aktiva yang memiliki subtansi (wujud) fisik, digunakan dalam operasi normal perusahaan (tidak dimaksudkan untuk dijual) dan memberikan manfaat ekonomi lebih dari satu tahun. Termasuk dalam sub-klasifikasi aktiva ini antara lain tanah, gedung, kendaraan, dan mesin serta peralatan.

b. Kewajiban (hutang)

Kewajiban yang merupakan utang perusahaan masa kini dapat disub-klasifikasi lebih lanjut menjadi tiga sub-klasifikasi, yaitu :

1) Kewajiban lancar

Kewajiban lancar yaitu kewajiban yang penyelesaiannya diharapkan akan mengakibatkan arus keluar dari sumber daya perusahaan (yang memiliki manfaat ekonomi) dalam jangka waktu satu tahun atau kurang. Termasuk dalam kategori kewajiban ini misalnya, utang dagang, utang wesel, utang gaji dan upah, utang pajak, dan utng biaya atau beban lainnya yang belum dibayar.

2) Kewajiban jangka panjang

Kewajiban jangka panjang yaitu kewajiban yang penyelesaiannya diharapkan akan mengakibatkan arus keluar dari sumber daya perusahaan (yang memiliki manfaat ekonomi) dalam jangka waktu lebih dari satu tahun. Termasuk dalam kategori kewajiban ini misalnya utang obligasi, utang hipotik, dan utang bank atau kredit investasi.

c. Ekuitas (modal)

Ekuitas yaitu merupakan bagian hak pemilik dalam perusahaan yang merupakan selisih antara aktiva dan kewajiban yang ada. Unsur ekuitas ini dapat disubklasifikasikan lebih jauh menjadi dua subklasifikasi, yaitu :

1) Ekuitas yang berasal dari setoran para pemilik misalnya modal sahan (termasuk agio saham bila ada).

2) Ekuitas yang beasal dari hasil operasi Yaitu laba yang tidak dibagikan kepada para pemilik, misalnya dalam bentuk deviden (ditahan).

2. Laporan laba-rugi

Menurut Dwi Prastowo dan rifka juliaty $(2007: 20)$ untuk dapat menggambarkan informasi mengenai potensi perusahaan dalam menghasilkan laba selama periode tertentu (kinerja) laporan laba-rugi mempunyai dua unsur, yaitu :

a. Penghasilan (income)

diartikan kenaikan manfaat dalam bentuk pemasukan atau peningkatan aktiva atau penurunan kewajiban (yang menyebabkan ekuitas selain yang berasal dari kontribusi pemilik) perusahaan selama periode tertentu dapat diklasifikasikan sebagai berikut :

1) Pendapatan (revenues)

Yaitu penghasilan yang timbul dalam pelaksanaan aktivitas yang biasa dan yang dikenal dengan sebutan berbeda, seperti 
misalnya penjualan barang dagang, penghasilan jasa (fees), pendapatan bunga, pendapatan deviden, royalties, dan sewa.

2) Keuntungan

Yaitu pos lain yang memenuhi depinisi penghasilan dan mungkin timbul dalam pelaksanaan aktivitas perusahaan yang rutin misalnya pos yang timbul dalam pengalihan aktiva lancar, revaluasi sekuritas, kenaikan jumlah aktiva jangka panjang.

\section{b. Beban (expense)}

Diartikan sebagai manfaat ekonomi dalam bentuk arus keluar, penurunan aktiva, atau kewajiban (yang menyebabkan penurunan ekonomis yang tidak menyangkut pembagian kepada pemilik) perusahaan selama periode tertentu dapat disubklasifikasikan sebagai berikut :

1) Beban

Timbul dalam pelaksanaan aktivitas perusahaan yang biasa (yang biasanya berbentuk arus keluar atau berkurangnya aktiva seperti kas, persediaan, aktiva tetap), yang meliputi harga pokok penjualan, gaji dan upah, penyusutan.

2) Kerugian

Mencerminkan pos lain yang memenuhi definisi beban yang timbul atau tidak timbul dari aktivitas perusahaan yang jarang terjadi, seperti misalnya rugi karena bencana kebakaran,banjir atau pelepasan aktiva tidak lancar.

Selisih antara total penghasilan dan beben disebut penghasilan bersih. Di dalam laporan laba rugi, keuntungan dan kerugian biasanya disajikan secara terpisah, sehingga akan memberikan informasi yang lebih baik dalam pengambilan keputusan ekonomi.

3. Laporan perubahan ekuitas

Merupakan suatu perubahan laporan atau mutasi laba yang ditahan yang merupakan bagian dari pemilik perusahaan untuk suatu periode tertentu. Dalam laporan laba ditahan ditunukan laba tidak dibagi awal periode, ditambah laba yang tercantum pada laporan laba-rugi yang dikurangi dengan deviden yang diumumkan selama periode tertentu.

4. Laporan arus kas

Laporan arus kas melaporkan arus kas masuk dan keluar dalam perusahaan pada suatu periode tertentu. Laporan arus kas ini menyediakan informasi yang berguna untuk mengetahui kemampuan perusahaan dalam menggunakan kas nya sehingga menghasilkan masukan yang berupa kas pula. Laporan arus kas terdiri dari tiga bagian :
1) Arus kas dari aktivitas operasi

2) Arus kas dari ativitas investasi

3) Aruskan dari aktivitas keuangan

\section{METODE PENELITIAN}

Definisi Operasional Variabel

Untuk meneliti analisis laporan keuangan dalam menilai kinerja keuangan perusahaan, ada dua variabel yang diukur sesuai dengan judul yang penulis tetapkan. Dua variabel yang dianalisis hubungannya yaitu :

\section{Variabel Independen}

Variabel Independen atau variabel tidak terikat (bebas), yaitu variabel yang dipengaruhi variabel lain yang tidak bebas. Dalam hubungannya dengan judul yang penulis tetapkan, yang menjadi variabel independen dalam penelitian ini adalah pelaksanaan analisis rasio keuangan.

\section{Variabel Dependen}

Variabel Dependen atau variabel terikat (tidak bebas), yaitu variabel yang dipengaruhi oleh variabel lainnya, yang sifatnya tidak berdiri sendiri serta menjadi perhatian utama peneliti maka yang menjadi variabel dependen dalam penelitian ini adalah kinerja perusahaan pada PT GUNUNG SALAK SUKABUMI di Sukabumi.

\section{Populasi dan Sampel}

Populasi yaitu merupakan sekumpulan orang-orang atau obyek yang memiliki kesamaan dalam satu atau beberapa hal yang membentuk masalah pokok dalam suatu riset khusus.

Agar penelitian yang dilakukan tidak terjadi kekeliruan dalam menganalisa ditetapkanlah populasi dan sampel. Populasi merupakan jumlah keseluruhan dari objek yang diteliti yaitu laporan keuangan pada PT GUNUNG SALAK SUKABUMI di Sukabumi.

Sampel adalah pengambilan data atas dasar contoh yang dianggap dapat mewakili populasi objek yang diteliti adapun yang menjadi sampel dari penelitian ini adalah neraca dan laba/rugi tahun 2013-2015 pada perusahaan PT GUNUNG SALAK SUKABUMI di Sukabumi.

\section{Instrumen Penelitian}

Untuk memperoleh pemecahan suatu masalah atau mendapatkan jawaban yang akurat dan benar atas pertanyaan tertentu, harus melalui rangkaian yang dilakukan secara 
terencana secara sistematis. Dimana langkah yang diambil harus serasi dan saling mendukung satu sama lain agar hasil penelitian memberikan kesimpulan-kesimpulan yang baik dan tidak meragukan. Dengan kata lain untuk memenuhi kualifikasi ilmiah didalam penyusunan skripsi ini perlu didukung oleh fakta dan data yang akurat.

\section{Teknik Pengumpulan Data}

Untuk memperoleh data dan informasi yang diperlukan dalam penelitian ini bersifat survei, sedangkan metode penelitian yang digunakan adalah metode deskriptif analitis. Yaitu metode yang berusaha mengumpulkan data yang sesuai dengan keadaan yang sebenarnya, menyajikan dan menganalisisnya sehingga dapat memberikan gambaran yang cukup jelas atas objek yang diteliti dan kemudian dapat ditarik suatu kesimpulan.

Untuk mendukung penulisan skripsi ini diperlukan data-data sebagai bahan untuk analisis. Data merupakan sumber bahan utama dalam skripsi. Data yang digunakan dalam penelitian ini adalah:

\section{Data kualitatif}

Data kualitatif adalah data deskriptif yang berupa ucapan, tulisan, kata, kalimat skema dan gambar. Data kualitatif ini adalah data sekunder yang mengalami proses pengolahan oleh sumbernya.

Data kualitatif yang akan dijadikan skripsi ini adalah data-data laporan keuangan yg terdiri dari neraca dan laporan laba rugi pada

\begin{tabular}{|lll|}
\hline \multicolumn{3}{|c|}{ Rasio Lancar $=\frac{\text { Aktiva Lancar }}{\text { Utang Lancar }}$} \\
\hline PT GUNUNG SALAK SUKABUMI di
\end{tabular}

Sukabumi.

\section{Data kuantitatif}

Data kuantitatif adalah data yang berbentuk angka-angka atau data kualitatif yang disajikan dalam bentuk angka. Data ini menunjukan nilai terhadap besaran atau variabel yang diwakilinya. Sifat data ini adalah data yang merupakan hasil pengamatan dalam suatu periode tertentu.

Teknik untuk pengumpulan data sekuder dilakukan dengan cara :

\section{Penelitian lapangan (Field Research)}

Penelitian lapangan ini bertujuan untuk memperoleh data dari perusahaan yang sedang diteliti untuk kemudian dipelajari, diolah dan dianalisis.

\section{Penelitian kepustakaan}

Penelitian kepustakaan adalah dengan cara mengumpulkan bahan-bahan dari berbagai sumber dan mempelajari literatur-literatur yang berhubungan dengan topik pembahasan untuk memperoleh data teoritis.

\section{Teknik Analisis Data}

Untuk melakukan analisa laporan keuangan PT GUNUNG SALAK SUKABUMI di Sukabumi penulis menggunakan teknik analisa kualitatif. Data kualitatif ini adalah data sekunder yang mengalami proses pngolahan oleh sumbernya.

Data kualitatif yang akan dijadikan skripsi ini adalah data-data laporan keuangan yg terdiri dari neraca dan laporan laba rugi pada PT GUNUNG SALAK SUKABUMI di Sukabumi.

Data yang didapat dalam penelitian ini diringkas dengan sedemikian rupa dengan baik dan teratur, hal ini bertujuan agar mendapat gambaran yang jelas sekumpulan data yang diperoleh baik mengenai populasi dan sampel.

Metode yang digunakan pada penelitian ini adalah dengan menggunakan metode Analisis rasio dengan menggunakan rasio likuiditas, solvabilitas, frofitabilitas,dan rasio aktivitas.

Berikut penjelasan singkat mengenai rasio keuangan diatas;

a. Rasio Likuiditas (Liquidity Ratio) terdiri dari;

1. Rasio lancar (Current Ratio) rumus :

1) Rasio cepat (Quick Ratio) rumus :

$\begin{array}{r}\begin{array}{c}\text { Kas }+ \text { Surat Berharga }+ \text { Piutang }=\text { A.Lancar }-(\text { Persediaan } \\ + \text { Prepaid Expense })\end{array} \\ \hline \text { Utang Lancar }\end{array}$

b. Rasio Solvabiltas (Leverage Ratio), terdiri dari ;

1) Rasio Utang atas Aktiva rumus :

$$
\text { Debt Ratio }=\frac{\text { Total Utang }}{\text { Total Aktiva }}
$$

2) Rasio Utang atas Modal (Debt to Equity Ratio) rumus :

Debt to Equity Ratio

$$
=\frac{\text { Total Utang }}{\text { Total Modal (Equity) }}
$$


c. Rasio Profitabilitas (profitability ratio) atau Rasio Rentabilitas,

1) Gross Profit Margin rumus :

Gross Profit Margin

$=\frac{\text { Penjualan }- \text { Harga pokok penjualan }}{\text { Penjualan }}$

2) Net Profit margin

rumus :

Net Profit Margin $=\frac{\text { Laba setelah pajak }}{\text { penjualan }}$

d. Rasio Aktivitas

Menurut harahap (2010 : 308-309) ada beberapa jenis rasio aktivitas yang dikemukakan sebagai berikut :

1) Inventory Turn Over rumus :

Inventory Turn Over

$=\frac{\text { Harga pokok penjualan }}{\text { Rata }- \text { rata persediaan barang }}$

2) Fixed Asset Turn Over

rumus :

Fixed Asset Turn Over

$$
=\frac{\text { Penjualan }}{\text { Aktiva Tetap Bersih }}
$$

3) Total Asset Turn Over

rumus:

Total Asset Turn Over $=\frac{\text { Penjualan }}{\text { Total asset }}$

\section{HASIL DAN PEMBAHASAN}

Hasil Penelitian

PT Gunung Salak Sukabumi dalam menyusun laporan keuangannya menggunakan format standar sebagaimana ditetapkan menurut peraturan yang berlaku. Laporan keuangan utama yang disusun adalah neraca dan laba/rugi. Laporan keuangan ini dususun mendasarkan pada catatan jurnal dan buku besar yang dilakukan oleh bagian accounting dan selanjutnya dicek oleh konsultan agar diperoleh laporan keuangan yang benar dan terstandar. Bagi perusahaan, laporan yang disusun ini memiliki fungsi penting dalam melihat kinerja perusahaan terutama dari sisi finansial. Dari laporan keuangan yang disusun juga dapat dibuat perencanaan untuk menetapkan strategi perusahaan ke depan dengan melihat kemampuan finansial perusahaan.

Dari laporan keuangan yang disusun juga dimanfaatkan untuk pertimbangan oleh Bank ketika perusahaan membutuhkan dana kredit dari bank untuk pengambangan usaha. Selain itu, laporan keuangan disertakan sebagai pelengkap untuk melaporkan pajak perusahaan. Adapun laporan keuangan PT. Gunung Salak Sukabumi tahun 2013 sampai dengan 2015 yang terdiri dari neraca dan laporan laba/rugi disajikan pada tabel IV.1 sampai dengan IV.2. 
TABEL IV.1

PT GUNUNG SALAK SUKABUMI

LAPORAN NERACA

31 Desember 2013 sampai dengan 2015

(Dalam ribuan)

\begin{tabular}{|c|c|c|c|}
\hline Keterangan & 2013 & 2014 & 2015 \\
\hline ASET LANCAR & & & \\
\hline Kas dan setara kas & 147,152 & 129,105 & 89,862 \\
\hline Investasi & 3,266 & 53,762 & 19,047 \\
\hline Piutang usaha & - & - & - \\
\hline Pihak berelasi & 157,604 & 197,871 & 241,139 \\
\hline Pihak ketiga & 31,830 & 6,629 & 7,532 \\
\hline Piutang lain-lain & 1,045 & 959 & 961 \\
\hline Persediaan bersih & 205,356 & 193,133 & 278,433 \\
\hline Uang muka & 767 & 1,005 & 5,770 \\
\hline Biaya dibayar dimuka & 4,357 & 4,826 & 4,645 \\
\hline Pajak dibayar dimuka & 11,594 & 23,501 & 24,491 \\
\hline Jumlah Aset Lancar & 562,971 & 610,791 & 671,880 \\
\hline ASET TIDAK LANCAR & - & - & - \\
\hline Piutang lain-lain & 251 & 139 & 1,478 \\
\hline Biaya dibayar dimuka & 1,138 & 1,315 & 977 \\
\hline Aset pajak tangguhan - bersih & 11,048 & 14,739 & 16,631 \\
\hline Aset tetap - setelah dikurangi akum, peny. & 399,856 & 396,756 & 416,328 \\
\hline Perangkat lunak komputer & 8,689 & 13,309 & 13,653 \\
\hline Beban tangguhan - hak atas tanah & 6,750 & 6,205 & 5,660 \\
\hline Uang jaminan & 3,917 & 3,986 & 4,255 \\
\hline Jumlah Aset Tidak Lancar & 431,650 & 436,449 & 458,983 \\
\hline JUMLAH ASET & 994,620 & $\mathbf{1 , 0 4 7 , 2 3 8}$ & $1,130,865$ \\
\hline
\end{tabular}

Sumber : PT. Gunung Salak Sukabumi 
(Dalam ribuan)

\begin{tabular}{|c|c|c|c|}
\hline Keterangan & 2013 & 2014 & 2015 \\
\hline \multicolumn{4}{|l|}{ KEWAJIBAN DAN EKUITAS } \\
\hline \multicolumn{4}{|l|}{ KEWAJIBAN LANCAR } \\
\hline Hutang Usaha pada pihak ketiga & 32,220 & 15,316 & 14,693 \\
\hline Hutang lain-lain pada pihak ketiga & 2,924 & 2,482 & 3,124 \\
\hline Hutang Pajak & 18,050 & 9,481 & 11,117 \\
\hline Biaya yang masih harus dibayar & 22,247 & 27,900 & 26,272 \\
\hline Jaminan Pelanggan & 2,070 & 1,987 & 2,010 \\
\hline Jumlah Kewajiban Lancar & 77,511 & 57,166 & 57,216 \\
\hline \multicolumn{4}{|l|}{ KEWAJIBAN TIDAK LANCAR } \\
\hline Hutang Hipotik, Obligasi, dll. & 36,312 & 41,592 & 53,236 \\
\hline \multicolumn{4}{|l|}{ EKUITAS } \\
\hline Modal Saham - nilai nominal & 100,533 & 100,533 & 100,533 \\
\hline Tambahan Modal disetor & 188,532 & 188,532 & 188,532 \\
\hline $\begin{array}{l}\text { Laba yang belum direalisasi atas } \\
\text { perubahan nilai wajar efek }\end{array}$ & 339 & 919 & 1,175 \\
\hline \multicolumn{4}{|l|}{ Saldo Laba } \\
\hline Ditentukan penggunaannya & 20,107 & 20,107 & 20,107 \\
\hline Tidak ditentukan penggunaannya & 571,286 & 638,390 & 710,066 \\
\hline Jumlah Ekuitas & 880,797 & 948,481 & $1,020,413$ \\
\hline $\begin{array}{l}\text { JUMLAH KEWAJIBAN DAN } \\
\text { EKUITAS }\end{array}$ & 994,620 & $1,047,239$ & $\mathbf{1 , 1 3 0 , 8 6 5}$ \\
\hline
\end{tabular}

Sumber : PT Gunung salak Sukabumi

Hasil penelitian yang didapatkan oleh penulis berdasarkan atas analisis laporan keuangan pada PT GUNUNG SALAK SUKABUMI. Laporan keuangan yang penulis teliti adalah laporan keuangan yang disusun pada periode 2013 sampai dengan 2015. Analisis rasio yang penulis gunakan untuk mengetahui kinerja perusahaan adalah analisis rasio keuangan menurut Sofyan Syafri Harahap (2009 : 301-309) yaitu sebagai berikut :
1. Rasio Likuiditas
2. Rasio Solvabilitas
3. Rasio Profitabilitas
4. Rasio Aktivitas

\section{Rasio Likuiditas}

Rasio likuiditas menggambarkan kemampuan perusahaan untuk membayar kewajiban finansial jangka pendeknya. Rasio ini ditunjukan oleh besar kecilnya aktiva lancar yaitu aktiva yang mudah untuk diubah menjadi kas yang meliputi : kas, surat berharga, piutang dan persediaan. Dengan menggunakan laporan yang terdiri atas neraca, laporan rugi laba dan laporan perubahan modal, maka rasio likuiditas PT GUNUNG SALAK SUKABUMI adalah sebagai berikut :

a. Rasio lancar (Current Ratio)

Rasio ini menunjukan sejauh mana aktiva lancar menutupi kewajiban-kewajiban lancar. Semakin besar perbandingan aktiva lancar dengan utang lancar semakin tinggi kemampuan perusahaan 
menutupi kewajiban jangka pendeknya rasio ini dihitung dengan menggunakan rumus :

$$
\text { Current Ratio }=\frac{\text { Aktiva Lancar }}{\text { Utang Lancar }}
$$

Untuk hasil perhitungan dapat dilihat pada tabel dibawah ini :

Tabel IV.3

Rasio Lancar

PT GUNUNG SALAK SUKABUMI Tahun 2013 -2015

(Dalam ribuan)

\begin{tabular}{|r|r|r|r|}
\hline Tahun & Aktiva Lancar & Utang lancar & \% Rasio \\
\hline 2013 & 562,971 & 77,510 & 7.3 \\
\hline 2014 & 610,791 & 57,165 & 10.7 \\
\hline 2015 & 671,880 & 57,216 & 11.7 \\
\hline
\end{tabular}

Sumber : data yang diolah

Dari hasil perhitungan diatas menunjukan bahwa rasio lancarnya dari tahun ke tahun mengalami kenaikan. Masing-masing nilai rasio lancarnya adalah : di tahun 2013 presentasenya 7,3 \% , ditahun 2014 presentasenya naik menjadi $10,7 \%$, kemudian di tahun 2015 meningkat lagi menjadi $11,7 \%$. Hal ini menunjukan bahwa perusahaan memiliki aktiva lancar yang mampu menutupi utanglancarnya, dengan demikian bisa dikatakan bahwa perusahaan ini likuid.

b. Rasio cepat (Quick Ratio)

Rasio ini menunjukan kemampuan aktiva lancar yang paling likuid mampu menutupi utang lancar.semakin besar rasio ini semakin baik. Rasio ini disebut juga Acid Test Ratio. Rasio ini dihitung dengan menggunakan rumus :

$$
\begin{array}{r}
\text { Kas }+ \text { Surat Berharga }+ \text { Piutang }= \\
+ \text { Aancar }-(\text { Persediaan } \\
+ \text { Prepaid Expense })
\end{array}
$$

Hasil perhitungan tampak pada tabel sebagai berikut :

\author{
Tabel IV.4 \\ Rasio Cepat \\ PT GUNUNG SALAK SUKABUMI \\ Tahun 2013 - 2015 \\ (dalam Ribuan)
}

\begin{tabular}{|r|r|r|r|r|}
\hline Tahun & Aktiva lancar & Persediaan & Utang lancar & \% Rasio \\
\hline 2013 & 562,971 & 205,355 & 77,510 & 4.0 \\
\hline 2014 & 610,791 & 193,132 & 57,165 & 7,3 \\
\hline 2015 & 671,880 & 278,433 & 57,216 & 6.9 \\
\hline
\end{tabular}

Sumber : data yang diolah

Dari hasil perhitungan diatas menunjukan bahwa rasio cepat dari tahun ketahun tidak stabil. Dari persentase di tahun 2013 sebesar 4,6 \% naik di tahun 2014 menjadi 7,3 \% kemudian di tahun 2015 turun lagi menjadi $6,9 \%$. Sehingga perusahaan ini dikatakan paling likuid pada tahun 2014 karena di tahun tersebut paling mampu untuk menutupi utang lancarnya.

Persentase kedua rasio likuiditas diatas dari tahun 2013 sampai dengan 2015 dapat dilihat dari tabel dibawah ini :

Tabel IV.5

Rasio Likuiditas

PT GUNUNG SALAK SUKABUMI

Tahun 2013 -2015

\begin{tabular}{|c|c|c|c|}
\hline \multicolumn{3}{|c|}{ tahun } \\
\hline \multirow{2}{*}{ Rasio } & \multicolumn{3}{|c|}{ (dalam ribuan) } \\
\cline { 2 - 4 } & 2013 & 2014 & 2015 \\
\hline Current Ratio & $7.30 \%$ & $10.70 \%$ & $11.70 \%$ \\
\hline Quick Ratio & $4.60 \%$ & $7.30 \%$ & $6.90 \%$ \\
\hline
\end{tabular}

Sumber: Data yang di olah

Dari kedua rasio likuiditas dapat disimpulkan bahwa rasio lancar dan rasio cepat nya dari tahun ketahun mengalami perbedaan yaitu pada rasio lancar mengalami kenaikan. hal ini terbukti dari tahun 2013 sampai dengan 2014 rasio lancarnya terus naik. sedangkan di rasio cepatnya terjadi ketidak stabilan, hal ini terbukti dari tahun 2013 ke tahun 2014 mengalami kenaikan. Dan mengalami penurunan ditahun 2015. Dengan demikian pada tahun 2015 perusahaan dapat menutupi hutang nya dan lebih likuid dibanding tahun 2014 dan 2013.

\section{Rasio Solvabilitas}

Rasio yang menggambarkan kemampuan perusahaan dalam membayar kewajiban jangka panjangnya. Rasio ini dapat dihitung dari pos-pos yang sifatnya jangka panjang seperti aktiva tetap dan utang jangka panjang, maka rasio solvabilitas PT Gunung Salak Sukabumi adalah : 
a. Rasio Utang atas Aktiva (Debt Ratio)

Rasio ini menunjukan sejauh mana utang dapat ditutupi oleh aktiva perusahaan. Apabila aktiva lebih besar dari pada utang maka perusahaan akan lebih aman (solvable).

Rasio ini menggunakan rumus :

$$
\text { Debt Ratio }=\frac{\text { Total Utang }}{\text { Total Aktiva }}
$$

Hasil perhitungan dapat dilihat pada tabel berikut :

Tabel IV.6

Debt Ratio

PT GUNUNG SALAK SUKABUMI Tahun 2013 - 2015

(Dalam ribuan)

\begin{tabular}{|c|r|r|c|}
\hline \multicolumn{1}{|l|}{ Tahun } & \multicolumn{1}{l|}{ Total Utang } & \multicolumn{1}{l|}{ Total Aktiva } & \% Rasio \\
\hline 2013 & 113,821 & 994,620 & 11.4 \\
\hline 2014 & 98,757 & $1,047,238$ & 9.4 \\
\hline 2015 & 110,451 & $1,130,865$ & 9.8 \\
\hline
\end{tabular}

Sumber : data yang diolah

Dari hasil perhitungan diatas menunjukan bahwa dari tahun 2013 sampai dengan tahun 2014 terjadi peningkatan aktiva dan ketidak stabilan utang perusahaan. Persentase utang dari tahun 2013 sebesar 11.4\% menurun ditahun 2014 sebesar $9.4 \%$ dan di tahun 2015 meningkat menjadi 9,8\%. Dengan demikian ditahun 2014 lebih baik dibanding tahun 2013 dan 2015. Lebih kecil presentasenya semakin baik, karena perusahaan mampu menutupi utangnya yang disebabkan oleh aktiva yang lebih besar.

b. rasio utang atas modal (Debt to Equity Ratio)

Rasio ini menggambarkan sampai sejauh mana modal pemilik dapat menutupi utang-utang kepada pihak luar. Semakin kecil rasio ini semakin baik. Rasio ini disebut juga rasio leverage. Rasio ini dapat dihitung dengan menggunakan rumus :

Debt to Equity Ratio $=\frac{\text { Total Utang }}{\text { Total Modal (Equity })}$

Hasil perhitungannya dapat dilihat pada tabel berikut :

Tabel IV.7

Debt Equity Ratio

PT GUNUNG SALAK SUKABUMI

Tahun 2013 - 2015

\begin{tabular}{|c|r|r|r|}
\hline \multicolumn{1}{|l|}{ Tahun } & \multicolumn{1}{|c|}{ Total Utang } & \multicolumn{1}{l|}{ Total Modal } & \% Rasio \\
\hline 2013 & 113,821 & 880,797 & 12.92 \\
\hline 2014 & 98,757 & 948,480 & 10.41 \\
\hline 2015 & 110,451 & $1,020,412$ & 10.82 \\
\hline
\end{tabular}

Sumber : data yang diolah

Dari hasil perhitungan diatas menunjukan bahwa debt equity ratio dari tahun 2013 sampai dengan tahun 2015 tidak stabil. Dapat dilihat dari tahun 2013 perusahaan hampir tidak mampu menutupi utangnya, karena ditahun 2013 presentase antara utang dengan modal 12,92 \%:100 \% atau 0,12:1 sedangkan ditahun 2014 presentase utang dengan modalnya $10,41 \%: 100 \%$ atau $0,10: 1$ dan ditahun 2015 sebesar 10,82\%: 100\% atau $0,10: 1$. Dengan demikian ditahun 2014 modal perusahaan lebih baik dibanding tahun 2015 yang kembali menurun karena modal perusahaan lebih kecil dibanding utang.

Persentase kedua rasio solvabilitas diatas dari tahun 2013 sampai dengan tahun 2015 dapat dilihat pada tabel dibawah ini.

Tabel IV.8

Rasio Solvabilitas

PT GUNUNG SALAK SUKABUMI

Tahun 2013 - 2015

\begin{tabular}{|l|c|c|c|}
\hline \multirow{2}{*}{ Rasio } & \multicolumn{3}{|c|}{ Tahun } \\
\cline { 2 - 4 } & 2013 & 2014 & 2015 \\
\hline Debt Ratio & 11.40 & 9.40 & 9.80 \\
\hline Debt to Equity Ratio & 12.92 & 10.41 & 10.82 \\
\hline
\end{tabular}

Sumber : data yang diolah

Dari kedua rasio solvabilitas diatas dapat disimpulkan bahwa antara kedua rasio tersebut dari tahun ke tahun sama-sama tidak stabil dari tahun 2013 ke tahun 2014 menurun, kemudian dari tahun 2014 ke 2015 meningkat. Semakin kecil rasio ini maka semakin baik. Sehingga pada tahun 2014 perusahaan dapat menutupi utangnya paling tinggi dari pada tahun 2013 dan 2015.

\section{Rasio Profitabilitas}

Rasio profitabilitas atau disebut juga rasio rentabilitas menggambarkan kemampuan perusahaan mendapatkan laba melalui semua kemampuan dan sumber yang ada seperti kegiatan penjualan, kas, modal, jumlah karyawan, jumlah cabang dan sebagainya. Rasio Profitabilitas PT Gunung Salak Sukabumi adalah : 
a. Gross Profit Margin

Rasio ini menunjukan berapa besar presentase pendapatan bersih yang diperoleh dari setiap penjualan. Semakin besar rasio ini semakin baik karena dianggap kemampuan perusahaan dalam mendapatkan laba cukup tinggi. Rumus yang digunakan :

$$
\begin{aligned}
& \begin{array}{l}
\text { GrossProfitMargin } \\
\text { penjualan }- \text { Harga pokok penjualan }
\end{array} \\
& \text { penjualan }
\end{aligned}
$$

Hasil perhitungan dapat dilihat pada tabel berikut :

Tabel IV.9

Gross Profit Margin

PT GUNUNG SALAK SUKABUMI Tahun 2013 -2015

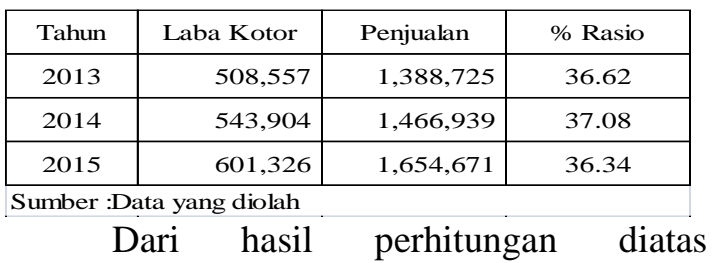
menunjukan bahwa perolehan perhitungan laba kotor perusahaan dari setiap penjualan dari tahun ke tahun tidak stabil. Dari persentase tahun 2013 sebesar 36,62 \% lalu tahun 2014 naik menjadi $37,08 \%$ dan menurun ditahun 2015 menjadi 36,34\% hal ini disebabkan karena kenaikan penjualan dibarengi dengan kenaikan harga pokok penjualan yang cukup tinggi sehingga laba kotor yang diperoleh naik turun sekitar $1 \%$.

\section{b. Net Profit Margin}

Rasio ini menunjukan berapa besar laba setelah pajak yang diperoleh dari setiap penjualan. Rasio ini menggunakan rumus :

Net profit Margin $=\frac{\text { Laba setelan pajak (EAT) }}{\text { Penjualan }}$

Hasil perhitungannya dapat dilihat pada tabel berikut

Tabel IV.10

Net Profit Margin

PT GUNUNG SALAK SUKABUMI

Tahun 2013-2015

\begin{tabular}{|c|c|c|c|}
\hline & & \multicolumn{2}{|}{ (dalam ribuan) } \\
\hline Tahun & EAT & Penjualan & \% Rasio \\
\hline 2013 & 124,612 & $1,388,725$ & 8.97 \\
\hline 2014 & 131,445 & $1,466,939$ & 8.96 \\
\hline 2015 & 140,039 & $1,654,671$ & 8.46 \\
\hline
\end{tabular}

Sumber : data yang diolah
Dari hasil perhitungan diatas menunjukan bahwa perolehan laba kotor perusahaan dari setiap penjualan dari tahun ketahun mengalami penurunan. Terlihat pada tahun 2013 presentasenya sebesar 8,97 \% ditahun 2014 menurun 0,01\% menjadi 8,96\% kemudian ditahun 2015 menurun lagi $0,5 \%$ menjadi $8,46 \%$.Penurunan tersebut sudah terlihat dari menurunnya laba kotor ditahun 2014 dan 2015 yang disebabkan oleh kenaikan penjualan yang tidak seimbang dengan kenaikan laba kotor. Sehingga setelah dikurangi biaya, laba bersih yang diperoleh semakin berkurang.

Dari kedua rasio profitabilitas diatas dapat dilihat pada tabel dibawah ini :

Tabel IV.11

Rasio profitabilitas

PT GUNUNG SALAK SUKABUMI Tahun 2013-2015

\begin{tabular}{|c|c|c|c|}
\hline \multirow{2}{*}{ Rasio } & \multicolumn{3}{|c|}{ Tahun } \\
\cline { 2 - 4 } & 2013 & 2014 & 2015 \\
\hline Gros Profit Margin & 36.62 & 37.08 & 36.34 \\
\hline Net Profit Margin & 8.97 & 8.96 & 8.46 \\
\hline
\end{tabular}

Sumber : Data yang diolah

Dari kedua rasio profitabilitas diatas dari tahun ketahun mengalami perbedaan yaitu rasio gros profit marginmenunjukan bahwa perolehan perhitungan laba kotor perusahaan dari setiap penjualan dari tahun ke tahun tidak stabil. Dari persentase tahun 2013 sebesar $36,62 \%$ lalu tahun 2014 naik menjadi 37,08 \% dan menurun ditahun 2015 menjadi 36,34\% hal ini disebabkan karena kenaikan penjualan dibarengi dengan kenaikan harga pokok penjualan yang cukup tinggi sehingga laba kotor yang diperoleh naik turun sekitar $1 \%$. Sedangkan net profit margin menunjukan bahwa perolehan laba kotor perusahaan dari setiap penjualan dari tahun ketahun mengalami penurunan. Terlihat pada tahun 2013 presentasenya sebesar 8,97 \% ditahun 2014 menurun $0,01 \%$ menjadi $8,96 \%$ kemudian ditahun 2015 menurun lagi $0,5 \%$ menjadi $8,46 \%$. Penurunan tersebut sudah terlihat dari menurunnya laba kotor ditahun 2014 dan 2015 yang disebabkan oleh kenaikan penjualan yang tidak seimbang dengan kenaikan laba kotor. Sehingga setelah dikurangi biaya, laba bersih yang diperoleh semakin berkurang.

\section{Rasio Aktivitas}

Rasio ini menggambarkan aktivitas yang dilakukan perusahaan dalam menjalankan 
operasinya baik dalam kegiatan penjualan, pembelian dan kegiatan lainnya.

Menurut harahap (2010 : 308-309) ada beberapa jenis rasio aktivitas yang dikemukakan sebagai berikut :

\section{a. Inventory Turn Over}

Rasio ini menunjukan berapa cepat perputaran persediaan dalam siklus produksi normal. Semakin besar rasio ini semakin baik karena dianggap bahwa kegiatan penjualan berjalan cepat.

Rata-rata persediaan dihitung dengan cara :

\begin{tabular}{|l|}
\hline$\frac{\text { Persediaan Awal + Persediaan Akhir }}{2}$ \\
Rumus yang digunakan : \\
$\begin{array}{l}\text { Inventory Turn Over } \\
=\frac{\text { Harga pokok penjualan }}{\text { Rata }- \text { rata persediaan barang }}\end{array}$
\end{tabular}

Hasil perhitungannya sebagai berikut

Tabel IV.12

Inventory Turn Over

PT GUNUNG SALAK SUKABUMI Tahun 2013-2015

\begin{tabular}{|c|c|r|c|}
\hline Tahun & Hpp & Rata-rata pers barang & \% rasio \\
\hline 2013 & 880,168 & 199,244 & 4.418 \\
\hline 2014 & 923,035 & 199,244 & 4.633 \\
\hline 2015 & $1,053,345$ & 235,783 & 4.467 \\
\hline
\end{tabular}

Dari perhitungan di atas menunjukan bahwa siklus perputaran persediaan dari tahun ke tahun tidak stabil. Pada tahun 2013 persentasenya adalah $4,418 \%$ naik di tahun 2014 sebesar 0,215\% presentasenta menjadi $4,633 \%$ namun mengalami penurunan di tahun 2015 sebesar $0,166 \%$ presentasenya menjadi 4,467\% Kenaikan ini disebabkan karena pada tahun 2013 dan 2015 rata-rata persediaan barang tetap sama jumlahnya namun pada harga pokok penujualan mengalami peningkatan. Meskipun harga pokok penjualan ditahun 2015 mengalami peningkatan namun pada tahun yang sama rata-rata persediaan barang dagang juga mengalami peningkatan sehingga tidak bepengaruh besar tehadap penjualan.

b. Fixed Asset Turn Over

Rasio ini menunjukan beberapa kali nilai aktiva berputar bila diukur dari volume penjualan. Semakin tinggi rasio ini semakin baik. Artinya kemampuan aktiva tetap menciptakan penjualan tinggi.
Rumus yang digunakan :

Fixed Asset Turn Over Penjualan

$=\overline{\text { Aktiva Tetap Bersih }}$

Hasil perhitungannya adalah sebagai

berikut

Tabel IV.13

Fixed Asset Turn Over

PT GUNUNG SALAK SUKABUMI

Tahun 2013-2015

\begin{tabular}{|l|r|r|c|}
\hline Tahun & \multicolumn{1}{|c|}{ Penjualan } & Aktiva tetap bersih & \% Rasio \\
\hline 2013 & $1,388,725$ & 431,650 & 3.217 \\
\hline 2014 & $1,466,939$ & 436,449 & 3.361 \\
\hline 2015 & $1,654,671$ & 458,983 & 3.605 \\
\hline
\end{tabular}

bahwa aktiva tetap mampu menciptakan penjualan yang tinggi, hal ini dapat dilihat dari peningkatan penjualan setiap tahun nya. Dari tahun 2013 sampai dengan 2015 terus mengalami kenaikan, di lihat dari persentase setiap tahun nya yaitu dari tahun $2013 \mathrm{ke}$ 2014 mengalami kenaikan sebesar 0,144 \% dan dari tahun 2014 ke 2015 mengalami kenaikan sebesar 0, $244 \%$. Hal ini dikarenakan penjualan dan aktiva tetap bersih terus meningkat, maka semakin tinggi rasio ini maka akan semain baik.

\section{c. Total Asset Turn Over}

Rasio ini menunjukan perputaran total aktiva diukur dari volume penjualan dengan kata lain, seberapa jauh kemampuan aktiva menciptakan penjualan. Maka semakin tinggi rasio ini semakin baik.

Rumus yang digunakan :

\begin{tabular}{|c|} 
Total Asset Turn Over $=\frac{\text { Penjualan }}{\text { Total asset }}$ \\
Hasil perhitungannya adalah sebagai
\end{tabular}
berikut :

Tabel IV.14

Total Asset Turn Over

PT GUNUNG SALAK SUKABUMI

Tahun 2013-2015

\begin{tabular}{|c|r|r|c|}
\hline Tahun & \multicolumn{1}{|c|}{ Penjualan } & \multicolumn{1}{c|}{ Total Asset } & \% Rasio \\
\hline 2013 & $1,388,725$ & 994,620 & 1.396 \\
\hline 2014 & $1,466,939$ & $1,047,239$ & 1.401 \\
\hline 2015 & $1,654,671$ & $1,130,865$ & 1.463 \\
\hline
\end{tabular}

Dari hasil perhitungan diatas menunjukan bahwa aktiva mampu menciptakan kenaikan penjualan dari tahun ke tahun. Terlihat pada penjualan yang semakin meningkat dan persentasenya pada tahun 2013 ke tahun 2014 
mengalami kenaikan sebesar 0,005 \% dan pada tahun 2014 ke tahun 2015 naik sebesar 0,062 \%. Hal ini terjadi karena kemampuan aktiva untuk menciptakan penjualan semakin tinggi maka semakin tinggi rasio ini akan semakin baik.

Dari ketiga rasio aktivitas dapat dilihat pada tabel di bawah ini :

Tabel IV.15

Rasio Aktivitas

PT GUNUNG SALAK SUKABUMI Tahun 2013-2015

\begin{tabular}{|c|c|c|c|}
\hline \multirow{2}{*}{ Rasio } & \multicolumn{3}{|c|}{ Tahun } \\
\hline & 2013 & 2014 & 2015 \\
\hline Inventory Turn Over & 4.418 & 4.633 & 4.467 \\
\hline Fixed Asset Turn Over & 3.217 & 3.361 & 3.605 \\
\hline Total Asset Turn Over & 1.396 & 1.401 & 1.463 \\
\hline
\end{tabular}

Sumber: Data yang Diolah

Dari ketiga rasio Aktivitas diatas dari tahun ketahun mengalami perbedaan yaitu rasio inventory turn over menunjukan perhitungan siklus perputaran persediaan dari tahun ke tahun tidak stabil. Pada tahun 2013 persentasenya adalah $4,418 \%$ naik di tahun 2014 sebesar $0,215 \%$ presentasenta menjadi $4,633 \%$ namun mengalami penurunan di tahun 2015 sebesar $0,166 \%$ presentasenya menjadi 4,467\% Kenaikan ini disebabkan karena pada tahun 2013 dan 2014 rata-rata persediaan barang tetap sama jumlahnya namun pada harga pokok penujualan mengalami peningkatan. Meskipun harga pokok penjualan ditahun 2015 mengalami peningkatan namun pada tahun yang sama rata-rata persediaan barang dagang juga mengalami peningkatan sehingga tidak bepengaruh besar tehadap penjualan. Sedangkan Fixed Asset Turn Over menunjukan bahwa aktiva tetap mampu menciptakan penjualan yang tinggi, hal ini dapat dilihat dari peningkatan penjualan setiap tahun nya. Dari tahun 2013 sampai dengan 2015 terus mengalami kenaikan, di lihat dari persentase setiap tahun nya yaitu dari tahun 2013 ke 2014 mengalami kenaikan sebesar $0,144 \%$ dan dari tahun 2014 ke 2015 mengalami kenaikan sebesar 0, $244 \%$. Hal ini dikarenakan penjualan dan aktiva tetap bersih terus meningkat, maka semakin tinggi rasio ini maka akan semain baik. Sedangkan Total Asset Turn Over menunjukan bahwa aktiva mampu menciptakan kenaikan penjualan dari tahun ke tahun. Terlihat pada penjualan yang semakin meningkat dan persentasenya pada tahun 2013 ke tahun 2014 mengalami kenaikan sebesar $0,005 \%$ dan pada tahun 2014 ke tahun 2015 naik sebesar 0,062 \%. Hal ini terjadi karena kemampuan aktiva untuk menciptakan penjualan semakin tinggi, maka semakin tinggi rasio ini akan semakin baik.

\section{KESIMPULAN}

Dari hasil perhitungan dan analisa laporan keuangan dengan menggunakan rasio likuiditas, rasio solvabilitas, rasio profitabilitas dan rasio aktivitas pada laporan keuangan PT Gunung Salak Sukabumi maka dapat ditarik kesimpulan yaitu :

1. Pada rasio likuiditas dari tahun 2013 sampai dengan 2015 aktiva lancar perusahaan mengalami kenaikan, masingmasing nilai rasio lancarnya adalah : ditahun 2013 presentasenya 7,3\% , ditahun 2014 presentasenya naik menjadi $10,7 \%$, kemudian di tahun 2015 meningkat lagi menjadi $11,7 \%$. Hal ini menunjukan bahwa perusahaan memiliki aktiva lancar yang mampu menutupi utang lancarnya, dengan demikian bisa dikatakan bahwa perusahaan ini likuid. Sedangkan cepat dari tahun ke tahun tidak stabil. Dari persentase di tahun 2013 sebesar 4,6\% naik di tahun 2014 menjadi 7,3\% kemudian di tahun 2015 turun lagi menjadi $6,9 \%$. Sehingga perusahaan ini dikatakan paling likuid pada tahun 2014 karena di tahun tersebut paling mampu untuk menutupi utang lancarnya walaupun persentasenya tidak stabil dari tahun ke tahun namun perusahaan masih mampu menutupi utang lancarnya. Dengan demikian perusahaan dalam keadaan baik atau sehat. Oleh karena itu, perusahaan harus mampu mempertahankannya untuk tahun-tahun berikutnya.

2. Pada rasio solvabilitas pada tahun 2014 kondisi keuangan perusahaan lebih baik dari pada tahun 2013 dan 2015. Persentase utang dari tahun 2013 sebesar 11.4\% menurun ditahun 2014 sebesar $9.4 \%$ dan di tahun 2015 meningkat menjadi 9,8\%. Dengan demikian ditahun 2014 lebih baik dibanding tahun 2013 dan 2015. Lebih kecil presentasenya semakin baik, karena perusahaan mampu menutupi utangnya yang disebabkan oleh aktiva yang lebih besar. Sedangkan di rasio utang atas modal ditahun 2013 presentase antara utang dengan modal 12,92 \%:100 \% atau 0,12:1 
sedangkan ditahun 2014 presentase utang dengan modalnya 10,41\% : $100 \%$ atau $0,10: 1$ dan ditahun 2015 sebesar 10,82\% : $100 \%$ atau $0,10: 1$. Dengan demikian Pada tahun 2014 modal perusahaan lebih baik dibanding tahun 2015 yang kembali menurun karena modal perusahaan lebih kecil dibanding utang. Maka, untuk tahun berikutnya perusahaan diharapkan mampu meningkatkan permodalannya.

3. Pada rasio profitabilitas dari tahun ketahun mengalami perbedaan yaitu rasio gros profit marginmenunjukan bahwa perolehan perhitungan laba kotor perusahaan dari setiap penjualan dari tahun ke tahun tidak stabil. Dari persentase tahun 2013 sebesar 36,62 \% lalu tahun 2014 naik menjadi $37,08 \%$ dan menurun ditahun 2015 menjadi 36,34 \% hal ini disebabkan karena kenaikan penjualan dibarengi dengan kenaikan harga pokok penjualan yang cukup tinggi sehingga laba kotor yang diperoleh naik turun sekitar $1 \%$. Sedangkan net profit marginmenunjukan bahwa perolehan laba kotor perusahaan dari setiap penjualan dari tahun ketahun mengalami penurunan. Terlihat pada tahun 2013 presentasenya sebesar 8,97 \% ditahun 2014 menurun $0,01 \%$ menjadi $8,96 \%$ kemudian ditahun 2015 menurun lagi $0,5 \%$ menjadi $8,46 \%$. Penurunan tersebut sudah terlihat dari menurunnya laba kotor ditahun 2014 dan 2015 yang disebabkan oleh kenaikan penjualan yang tidak seimbang dengan kenaikan laba kotor. Sehingga setelah dikurangi biaya, laba bersih yang diperoleh semakin berkurang. Oleh karena itu, diharapkan untuk tahun berikutnya perusahaan dapat mengefisiensikan biayabiaya perusahaan dan meningkatkan penjualan.

4. Pada rasio Aktivitas dari tahun ketahun mengalami perbedaan yaitu rasio inventory turn over menunjukan perhitungan siklus perputaran persediaan dari tahun ke tahun tidak stabil. Pada tahun 2013 persentasenya adalah $4,418 \%$ naik di tahun 2014 sebesar $0,215 \%$ presentasenta menjadi 4,633\% namun mengalami penurunan di tahun 2015 sebesar $0,166 \%$ presentasenya menjadi $4,467 \%$ Kenaikan ini disebabkan karena pada tahun 2013 dan 2015 rata-rata persediaan barang tetap sama jumlahnya namun pada harga pokok penujualan mengalami peningkatan. Meskipun harga pokok penjualan ditahun 2015 mengalami peningkatan namun pada tahun yang sama rata-rata persediaan barang dagang juga mengalami peningkatan sehingga tidak bepengaruh besar tehadap penjualan. Sedangkan Fixed Asset Turn Over menunjukan bahwa aktiva tetap mampu menciptakan penjualan yang tinggi, hal ini dapat dilihat dari peningkatan penjualan setiap tahun nya. Dari tahun 2013 sampai dengan 2015 terus mengalami kenaikan, di lihat dari persentase setiap tahun nya yaitu di tahun 2013 presentasinya sebesar 3,217\% dan 2014 mengalami kenaikan sebesar 0,144\% menjadi 3,361 \%. Kemudian pada tahun 2015 mengalami kenaikan sebesar 0, 244 $\%$ menjadi 3,605 \%. Hal ini dikarenakan penjualan dan aktiva tetap bersih terus meningkat, maka semakin tinggi rasio ini maka akan semain baik. Sedangkan Total Asset Turn Over menunjukan bahwa aktiva mampu menciptakan kenaikan penjualan dari tahun ke tahun. Terlihat pada penjualan yang semakin meningkat, pada tahun 2013 presentasenya 1,396\% dan pada tahun 2014 mengalami kenaikan sebesar $0,005 \%$ menjadi $1,401 \%$ kemudian pada tahun 2015 naik sebesar $0,062 \%$ menjadi $1,463 \%$. Hal ini terjadi karena kemampuan aktiva untuk menciptakan penjualan semakin tinggi, maka semakin tinggi rasio ini akan semakin baik.

\section{SARAN}

Dari kesimpulan di atas, penulis mempunyai beberapa saran untuk PT Gunung Salak Sukabumi. sebagai berikut :

1. Pada rasio Likuiditas dari tahun 2013 sampai dengan tahun 2015 aktiva lancar perusahaan mengalami kenaikan, walaupun persentase nya tidak stabil dari tahun ke tahun namun perusahaan masih mampu menutupi utang lancarnya. Dengan demikian perusahaan dalam keadaan baik atau sehat. Oleh karena itu, perusahaan harus mampu mempertahankannya untuk tahun-tahun berikutnya.

2. Pada rasio Solvabilitas pada tahun 2014 kondisi keuangan perusahaan lebih baik daripada tahun 2013 dan 2015. Pada tahun 2014 modal perusahaan lebih baik dibanding tahun 2015 yang kembali menurun karena modal perusahaan lebih kecil dibanding utang. Maka, untuk tahun 
berikutnya perusahaan diharapkan mampu untuk meningkatkan permodalannya.

3. Pada rasio Profitabilitas dari tahun ke tahun mengalami kenaikan yang disebabkan kenaikan laba yang tidak seimbang dengan kenaikan penjualan. Sehingga setelah dikurangi biaya, laba bersih yang diperoleh semakin berkurang. Oleh karena itu, diharapkan untuk tahun berikutnya perusahaan dapat mengefisiensikan biaya-biaya perusahaan dan meningkatkan penjualan.

4. Pada rasio Aktivitas dari tahun ketahun mengalami kenaikan karena penjualan terus meningkat. Oleh karena itu, diharapkan untuk tahun berikutnya perusahaan dapat mempertahankan atau bahkah perusahaan meningkatkan lagi penjualannya.

\section{DAFTAR PUSTAKA}

Ikatan Akuntansi Indonesia (IAI) Standar Akuntansi Keuangan, Salemba Empat Jakarta 2007.

Budi Rahardjo, Laporan Keuangan Perusahaan, Gadjah Mada University Press, Yogyakarta, 2009.

Depdiknas, Kamus Besar Bahasa Indonesia, Balai Pustaka, 2010.

Achmad Komaruddin, Investigasi Motivasi dan Strategi Manajemen Laba pada Perusahaan Publik Indonesia, Simposium Nasional Akuntansi X, Vol 8, Jakarta, 2008.

Dwi Prastowo dan Rifka Juliaty, Analisis Laporan Keuangan (Konsep dan Aplikasi), UPP AMP YKPN Yogyakarta, 2007.

Mulyadi, Akuntansi Manajemen, Salemba Empat Jakarta 2007.

Sofyan Safri Harahap, Analisis Kritis atas Laporan Keuangan, PT. Raja Grafindo Persada Jakarta, 2009.

Sugiono Arief, Manajemen Keuangan Untuk Praktisi Keuangan, Grasindo Jakarta, 2009.

Rivai, Veithzal dan Ahmad Fawzi Mohd Basri, Zaki, Performance Appraisal. PT. Raja Grafindo Persada, Jakarta. 2007.

Munawir, S. Analisis Laporan Keuangan, Liberty Yogyakarta, 2007.

Kasmir, 2010. Analisis Laporan Keuangan www.Geogle.com. 